\title{
EFEKTIVITAS PEMBUATAN PERATURAN DAERAH KHUSUS DI PROVINSI PAPUA (Studi Majelis Rakyat Papua)
}

\author{
Hamjah Bonso ${ }^{1}$ \\ Herman Lawelai $^{2}$ \\ Dosen Program Ilmu Pemerintahan, IISIP Yapis Biak, Indonesia \\ Dosen Ilmu Pemerintahan Universitas Muhammadiyah Buton, Indonesia \\ bonsohamjah1712@gmail.com
}

\section{Keyword: Effectiveness; Perdasus; MRP.}

Kata Kunci:

Efektivitas;

Perdasus;

$M R P$.

\begin{abstract}
The presence of the special autonomy law in Papua has had an impact on institutions. This can be seen with the formation of the Papua People's Assembly (MRP). This study aims to determine the effectiveness of making specific regional regulations in the province of Papua. This study uses a "triangulation" method that combines qualitative and quantitative methods with data collection techniques, namely interviews, documentation, and questionnaires. The results showed that the Papuan People's Assembly (MRP) in making special regional regulations (Perdasus) was already quite effective, which can be seen from the involvement of the MRP which scored 1,35 (moderate), MRP commitment 2,05 (high), the role of MRP 2,0 (high), and the implementation of the MRP mechanism 2,1 (high).
\end{abstract}

\section{PENGANTAR}

Abstrak: Hadirnya undang-undang otonomi khusus di Papua memberikan dampak terhadap kelembagaan. Hal ini terlihat dengan terbentuknya lembaga Majelis Rakyat Papua (MRP). Penelitian ini bertujuan untuk mengetahui efektivitas pembuatan peraturan daerah khusus di provinsi Papua. Penelitian ini menggunakan metode "triangulasi" yang menggabungkan metoe kualitatif dan kuantitatif dengan teknik pengumpulan data yaitu wawancara, dokumentasi, dan kuisioner. Hasil penelitian menunjukkan bahwa Majelis Rakyat Papua (MRP) dalam pembuatan peraturan daerah khusus (Perdasus) sudah cukup efektif yan dapat dilihat dari keterlibatan MRP memperoleh nilai 1.35 (sedang), komitmen MRP 2.05 (tinggi), peran MRP 2,0 (tinggi), dan pelaksanaan mekanisme MRP 2,1 (tinggi).

Desentralisasi di Indonesia yang saat ini sedang berlangsung merupakan wujud nyata dari prinsip-prinsip demokrasi yang tidak dapat ditarik kembali dalam wujud sentralisasi. Reformasi politik yang terjadi pada tahun 1998 telah mengamanatkan pelbagai peluang dalam menata kembali kehidupan dalam bidang politik, dan tidak terkecuali dalam pola hubungan pusatdaerah (Mallarangeng, 2006). Perkembangan dimensi demokratisasi dalam pemerintahan lokal menghantarkan makna desentralisasi kepada pendekatan politik (devolusi) dan pendekatan administrasi (dekonsentrasi).

Otonomi khusus baru dikenal dalam sistem pemerintahan negara Indonesia di era reformasi. Secara resmi otonomi khusus menjadi bagian dari sistem penyelenggaraan negara melalui perubahan kedua UUD 1945, Bab VI Pemerintahan Daerah pasal 18 ayat (1) yang mengatakan: "Negara Kesatuan Republik Indonesia dibagi menjadi atas daerah-daerah provinsi dan daerah itu dibagi atas kabupaten dan kota, yang tiap-tiap provinsi, kabupaten, dan kota itu mempunyai pemerintahan daerah, yang diatur dengan Undang-undang". Yang kemudian pada ayat (2) mengatakan "pemerintah daerah provinsi, daerah kabupaten, dan kota mengatur dan mengurus sendiri urusan pemerintahan menurut asas otonomi dan tugas pembantuan" (Kaho, 2012). 
Kehadiran lembaga MRP tentunya memberikan dampak yang positif dalam penyelenggaraan pemerintahan daerah, dimana lembaga ini merupakan lembaga repsentatif masyarakat Papua yang memiliki wewenang tertentu dalam rangka perlindungan hak-hak orang asli Papua dengan berlandaskan pada penghormatan terhadap adat dan budaya, pemberdayaan perempuan, dan pemantapan kerukunan hidup beragama.

Sebagai lembaga representatif masyarakat Papua, lembaga MRP memiliki kewenangan dalam hal penyelenggaraan pemerintahan. Kewenangan MRP ini terlihat pada keterlibatannya dalam pembuatan produk peraturan daerah, sebagaimana yang diatur dalam Undang-undang No. 21 tahun 2001 menyatakan bahwa MRP berhak memberikan pertimbangan dan persetujuan terhadap Perdasus yang dibuat dan ditetapkan oleh DPRP bersama-sama Gubernur. Pelaksanaan pemberian pertimbangan dan persetujuan oleh MRP dipertegas kembali pada pasal 29 ayat 3 menyatakan tata cara pemberian pertimbangan dan persetujuan MRP diatur dalam Perdasi.

Dengan adanya Undang-undang No. 21 tahun 2001 Otsus Papua, MRP diharapkan mampu memberikan kontribusi yang besar dalam penyelenggaraan pemerintahan di provinsi Papua khususnya dalam memperhatikan hak-hak orang asli Papua. Keterlibatan MRP dalam memberikan pertimbangan dan persetujuan pembuatan Perdasus yang telah diatur dalam undang-undang Otsus Papua, diatur juga oleh Peraturan Pemerintah No. 54 tahun 2004 bab IX tentang dalam pelaksanaan tugas dan wewenang MRP.

Perspektif efektivitas sesunggungnya bersumber dari salah satu kriteria ilmu administrasi yang berkembang secara alamiah ke dalam berbagai aktivtias kehidupan manusia untuk mencapai tujuan yang mereka kehendaki (Makmur, 2011). Konsep efektivitas sendiri telah banyak dikemukakan oleh para ahli organisasi maupun manajemen dan memiliki makna yang berbeda tergantung kepada kerangka acuan yang dipergunakan.

Wisnu dan Nurhasanah (2005) mengemukakan bahwa suatu organisasi efektif jika (1) mengamankan skill dan sumber daya langka dari luar; (2) secara kreatif mengkoordinasikan sumber daya dengan skill karyawan untuk menemukan produk dan berselaras dengan perubahan kebutuhan konsumen (pendekatan system-sistem internal); dan (3) secara efisien mengubah skill dan sumber daya menjadi barang dan jasa (pendekatan teknis).

Provan \& Kenis (2007) mengatakan bahwa network governance forms can be categorized along two different dimensions:

First, network governance may or may not be brokered. A second distinction regarding governance can be made in brokered networks byfocusing on whether the network is participant governed or externally governed.

Dengan melihat kedua dimensi berbeda yang telah diuraikan diatas, selanjutnya Provan \& Kenis (2007) membagi network governance menjadi dua bentuk yaitu participant-networks governed dan network administrative organization. Kedua bentuk tersebut menurut Provan \& Kenis dapat dijadikan alasan dalam pelaksanaan jaringan pemerintahan walaupun memang diakui dari masing-masing bentuk ini memiliki kekuatan dan kelemahan tertentu.

Bentuk pertama adalah participant-networks governed yang merupakan bentuk paling sederhana dan umum dalam penyelenggara peserta pemerintahan. Bentuk ini diatur oleh jaringan mereka sendiri dengan tidak ada entity governance yang terpisah. Bentuk pemerintahan ini dapat dicapai secara formal, misalnya pertemuan rutin dari perwakilan organisasi yang ditunjuk, atau lebih informal melalui upaya yang sedang berlangsung tetapi biasanya tidak terkoordinasi dari orang-orang yang memiliki kepentingan dalam keberhasilan jaringan. Pada satu sisi, pengaturan peserta jaringan dapat tersedentralisasi dengan melibatkan 
sebagian besar atau seluruh anggota jaringan berinteraksi secara relatif sama dalam proses pemerintahan. Hal ini yang dikatakan sebagai penyelenggaraan pemerintahan bersama.

Bentuk kedua adalah network administrative organization. Bentuk ini memberikan ide dasar bahwa keberadaan administrasi yang terpisah diatur secara khusus untuk mengatur jaringan dan kegiatannya, walaupun peserta jaringan masih berinteraksi satu sama lainnya. Perantara jaringan dalam hal ini network administrative organization dapat memainkan peran sebagai kunci dalam mengkoordinasikan dan mempertahankan jaringan.

Sebuah network administrative organization mungkin sederhana dalam skala bentuk jaringan pemerintahan. Sehingganya jaringan ini sering disebut sebagai fasilitator/perantara jaringan pemerintahan. Bentuk jaringan organisasi administrasi dapat digunakan sebagai mekanisme untuk meningkatkan legitimasi jaringan dalam menangani masalah yang unik dan kompleks serta mengurangi kompleksitas masalah pemerintahan.

Tabel. 1

Form Network Governcance

\begin{tabular}{|l|l|}
\hline Form Network Governance & Dimension Network Governance \\
\hline Participant network governed & $\begin{array}{l}\bullet \text { Involvement network organization } \\
\bullet \text { Commitment network organization }\end{array}$ \\
\hline Network administrative organization & $\begin{array}{l}\bullet \text { Role of network organization } \\
\bullet \text { Mechanism network organization }\end{array}$ \\
\hline
\end{tabular}

Sumber: Elaborasi penulis dari Provan dan Kenis (2007).

Dengan melihat beberapa landasan teori diatas, sebagaimana yang dikatakan oleh Provan dan Kenis (2007) dapat simpulkan bahwa efektivitas network governance akan terlaksana jika memperhatikan kedua bentuk network governance yaitu participant-governed network dan network administrative organization

\section{METODE PENELITIAN}

Penelitian ini menggunakan metode "triangulasi" yaitu menggabungkan metode penelitian kualitatif dan kuantitatif dengan cara mengintegrasikan metode analisis isi (content analysis) kuantitatif dengan teknik wawancara mendalam. Strategi triangulasi adalah penggabungan metode penelitian kualitatif dan kuantitatif untuk menghasilkan gambaran yang lebih lengkap tentang fenomena yang akan diteliti (Kelle, 2001).

Penelitian ini dilakukan pada kantor/lembaga Majelis Rakyat Papua (MRP) di provinsi Papua.Teknik pengumpulan data yang digunakan dalam penelitian ini yaitu: wawancara, dokumentasi, dan kuisioner.Sumber data primer dalam penelitian ini didapatkan pada sebuah data yang dihasilkan. Data primer adalah data yang diperoleh secara langsung di lapangan yang bersumber dari hasil angket (kuisioner) dan wawancara di kantor Majelis Rakyat Papua (MRP). Angket dan wawancara yang dilakukan terhadap informan/responden digunakan sebagai data primer.Data sekunder merupakan data pendukung sebagai pelengkap data primer yang diperoleh melalui dokumen-dokumen yang mencatat keadaan konsep penelitian yang dilakukan.

Analisis data kualitatif dalam situs ini akan dilakukan dengan menggunakan rancangan analisis data menurut model interaksi(Sugiyono, 2014). Sedangkan analisis data kuantitatif berdasarkan penghitungan skala interval kelas tersebut, dapat dilihat pada tabel berikut: 
Tabel. 2

Kategori Interpretasi

\begin{tabular}{c|c}
\hline Kategori & Interval \\
\hline Tinggi & $2,00-2,66$ \\
Sedang & $1,33-1,99$ \\
Rendah & $0,66-1,32$ \\
\hline
\end{tabular}

\section{HASIL DAN DISKUSI}

\section{a. Keterlibatan MRP}

Keterlibatan MRP dalam memberikan pertimbangan dan persetujuan pembuatan/pernyusunan Perdasus diatur kembali oleh Perdasus No. 3 tahun 2008 tentang pelaksanaan hak dan kewajiban MRP.Selain itu keterlibatan MRP diatur juga dalam Perdasus No. 4 tahun 2008 tentang pelaksanaan tugas dan wewenang MRP. Pada Pasal 8 Perdasus No. 4 tahun 2008 mengatakan DPRP menyampaikan rancangan Perdasus hasil pembahasan Gubernur dan DPRP kepada MRP untuk mendapatkan pertimbangan dan persetujuan.

Jika melihat kewenangan yang dimiliki oleh MRP, maka menjadikan MRP sebagai institusi yang terlibat dalam penyelenggaraan pemerintahan provinsi Papua. Untuk itu, keberadaan MRP akan sangat diperlukan dalam menopang pemerintahan daerah Papua karena segala bentuk peraturan DPRP dan Gubernur bisa menjadi timpang dan tujuan dari otonomi khusus tidak terlaksana sebagaimana yang telah diamanatkan Undang-undang No. 21 tahun 2001.Keterlibatan MRP dalam penyelenggaraan pemerintahan daerah terhadap pembuatan/penyusunan Perdasus yang kemudian diperjelas dari hasil wawancara dengan Ketua MRP yang mengatakan bahwa:

"Dengan adanya undang-undang Otsus Papua memberikan konsekuensi untuk dibentuknya Majelis Rakyat Papua (MRP), MRP disini mempunyai hak dan kewenangan sebagai lembaga kultur dan lembaga negara di daerah yang diatur dalam undang-undang dan peraturan daerah provinsi.Kami dilingkungan MRP, dalam hal memberikan pertimbangan dan persetujuan Raperdasus selalu mengacu pada peraturan perundangundangan dan kami harus menjalankan itu karena menyangkut hak-hak orang asli Papua sebagai representatif masyarakat Papua.

Sebagai mitra kerja lembaga pemerintahan daerah provinsi dalam melaksanakan Otsus Papua, MRP merupakan bagian yang tak terpisahkan atau satu kesatuan dari DPRP dan Gubernur yang memiliki derajat yang sama dalam membuat keputusan (decision making). Untuk itu, keterlibatan MRP dalam pemberian pertimbangan dan persetujuan terhadap Raperdasus sangat penting.

MRP dalam melaksanakan tugas dan fungsinya sebagai lembaga representatif masyarakat kultur Papua selalu mengacu pada undang-undang Otsus Papua.Tujuannya untuk memberikan pertimbangan dan persetujuan terhadap pembuatan Perdasus. Selama ini keterlibatan MRP terhadap Perdasus hanya sekedar memberikan pertimbangan dan pertimbangan, tidak terlibat secara langsung baik dalam proses penyusunan hingga pengesahan. 
MRP mempunyai tugas dan wewenang telah diatur dalam UU No. 21 tahun 2001 pasal 20 ayat $\mathrm{C}$ memberikan pertimbangan dan persetujuan terhadap rancangan Perdasus yang kemudian dijabarkan dalam peraturan No. 54 tahun 2004, Inilah yang mendasari kami dalam pelaksanaan tugas dan kewenangan MRP. Kami khususnya di MRP terkait keterlibatan dalam pembuatan Perdasus hanya memberikan pertimbangan dan persetujuan tidak mempunyai hak dalam penyusunan rancangan Perdasus. Jadi keterlibatan MRP sudah berjalan karena dengan adanya Perdasus No. 3 dan 4 tahun 2008 inilah yang kemudian yang menjadi dasar MRP dalam memberikan pertimbangan dan persetujuan. Selain itu, diatur juga dalam keputusan MRP No. 1 tahun 2005.

Keterlibatan MRP dalam melaksanakan tugas dan wewenangnya untuk terhadap pembentukan Perdasus dalam konteks memberikan pertimbangan dan persetujuan terhadap rancangan Perdasus dapat dilihat pada tabel V.4 dibawah ini:

Tabel. 3

Keterlibatan Lembaga MRP Dalam Memberikan Pertimbangan dan Persetujuan Raperdasus

\begin{tabular}{|c|c|c|c|}
\hline \multirow{2}{*}{ Agenda Sidang } & \multicolumn{2}{|c|}{ MRP } & \multirow{2}{*}{ Persentase } \\
\hline & Hadir & $\begin{array}{l}\text { Tidak } \\
\text { Hadir }\end{array}$ & \\
\hline Orang Asli Papua. & 37 & 5 & $\mathbf{8 8 \%}$ \\
\hline Tata Cara Pemilihan Anggota MRP. & 34 & 8 & $80 \%$ \\
\hline $\begin{array}{l}\text { Perubahan Perdasus No. } 25 \text { Tahun } 2013 \text { tentang } \\
\text { Penerimaan Pengelolaan Keuangan DOK. }\end{array}$ & 39 & 3 & $92 \%$ \\
\hline $\begin{array}{l}\text { Perubahan Perdasus No. } 6 \text { Tahun } 2014 \text { tentang } \\
\text { Keanggotaan DPRP yang ditetapkan melalui } \\
\text { Mekanisme Pengangkatan periode 2014-2019. }\end{array}$ & 28 & 14 & $66 \%$ \\
\hline Pengelolaan Pertambangan Mineral dan Batubara. & 31 & 11 & $73 \%$ \\
\hline
\end{tabular}

Sumber: Data primer diolah dari Risalah sidang MRP.

Mencermati dari hasil wawancara yang dilakukan dengan beberapa informan dan data yang diperoleh, maka keterlibatan MRP dalam penyusunan/pembuatan Perdasus sangat terbatas dengan kewenangan yang dimilikinya berdasarkan ketentuan peraturan.Kewenangan lembaga MRP hanya melakukan pemberian pertimbangan dan persetujuan pada peraturan daerah khusus (Perdasus). Walaupun kewenangan yang dimiliki lembag MRP sangat terbatas, namun lembaga MRP dalam proses memberikan pertimbangan dan persetujuan terhadap Perdasus sudah terlaksana dengan maksimal, hal ini ditandai dengan jumlah presentasi kehadiran anggota MRP melebihi 50\% kehadiran dalam sidang pemberian pertimbangan dan persetujuan.

Keterlibatan lembaga pemerintahan provinsi Papua dalam hal ini Majelis Rakyat Papua (MRP) dari hasil jawaban responden sebanyak 20 orang makalembaga Majelis Rakyat Papua (MRP) tidak terlalu terlibat dengan mendapatkan nilai 1,35 (Sedang). Hal ini dikarenakan lembaga MRP hanya berada pada tingkat memberikan persetujuan saja terhadap rancangan yang telah disepakati oleh eksekutif dan legistatif. 


\section{b. Komitmen MRP}

Komitmen MRP dalam memberikan pertimbangan dan persetujuan terhadap pembuatan/pernyusunan Perdasus diatur kembali oleh Perdasus No. 3 tahun 2008 tentang pelaksanaan hak dan kewajiban MRP.Selain itu lembaga MRP untuk melaksanakan tugas dan wewenangnya diatur juga dalam Perdasus No. 4 tahun 2008. Pada Pasal 8 Perdasus No. 4 tahun 2008 mengatakan DPRP menyampaikan rancangan Perdasus hasil pembahasan Gubernur dan DPRP kepada MRP untuk mendapatkan pertimbangan dan persetujuan.

Jika melihat kewenangan yang dimiliki oleh MRP, maka menjadikan MRP sebagai institusi yang terlibat dalam penyelenggaraan pemerintahan provinsi Papua. Untuk itu, keberadaan MRP akan sangat diperlukan dalam menopang pemerintahan daerah Papua terhadap pembentukan/pembuatan Perdasus. Apabila hal ini tidak terlaksana, maka amanat didalam Undang-undang No. 21 tahun 2001 tidak dilaksanakan dengan baik. Oleh karena itu, komitmen MRP dalam menjalankan tugas dan wewenangnya sangat diperlukan guna menghasilkan produk peraturan daerah yang sifatnya khsusus untuk tercapainya tujuan Otsus Papua.

Sebanyak 42 orang anggota MRP dalam menjalankan tugas dan wewenang selalu mengacu pada undang-undang Otsus.Selain itu juga, pada produk peraturan daerah dan peraturan lainnya yang berkaitan dengan kewenangan MRP. Setiap anggota MRP harus melaksanakan hal ini tersebut karena apabila itu tidak dilaksanakan, maka akan mendapatkan teguran dari pemerintah Pusat. Pada sisi yang lain, jika itu tidak dilaksanakan berarti dapat dikatakan gagal menjadi anggota MRP yang telah dipercayakan oleh rakyat Papua.

Sebagai mitra kerja lembaga pemerintahan daerah provinsi dalam pelaksanaan Otsus Papua, MRP merupakan bagian yang tak terpisahkan atau satu kesatuan dari DPRP dan Gubernur yang memiliki derajat yang sama dalam membuat keputusan (decision making). Untuk itu, lembaga MRP dalam pemberian pertimbangan dan persetujuan terhadap Raperdasus sangat sangat diperlukan.

MRP sebagai lembaga kultur masyarakat Papua yang memilki tugas dan wewenang untuk memberikan pertimbangan dan persetujuan terhadap Raperdasus dan merupakan salah satu lembaga yang terbentuk setelah ditetapkan undang-undang Otsus Papua, maka MRP harus melaksanakan tugas dan wewenangnya itu sesuai dengan aturan yang mengatur khususnya MRP. Karena itu merupakan dasar atas penyelenggaraan lembaga ini, yang tentunya tidak bisa terlepas dari segala bentuk peraturan yang mengikat dalam pelaksanaan tugas dan wewenang terhadap pemberian pertimbangan dan persetujuan yang dimaksud.

MRP bekerja menurut undang-undang dan peraturan lainnya yang berkaitan dengan tugas dan wewenang MRP yang terbagi berdasarkan kelompok-kelompok kerja.Selain itu, dituntut juga untuk bekerja secara maksimal dalam memberikan pertimbangan dan persetujuan terhadap Raperdasus karena di MRP sendiri sudah diatur dalam tata tertib MRP tentang tugas dan wewenang dari masing-masing kelompok kerja. Dan juga mereka sudah bekerja dengan baik terhadap pembahasan Raperdasus dalam memberikan pertimbangan dan persetujuan dimaksud.

Hasil wawancara dengan beberapa narasumber diatas menunjukkan bahwa lembaga MRP dalam melaksanakan kewenangan yang dimilikinya untuk memberikan pertimbangan dan persetujuan terhadap Raperdasus dapat dikatakan terlaksana dengan baik, hal ini ditandai dengan tingkat presentasi kehadiran anggota MRP dari masing-masing kelompok kerja yang menunjukan melebihi 50\%.Tingkat kehadiran anggota MRP yang begitu antusias 
dari masing-masing kelompok kerja ini dikarenakan setiap kelompok kerja ada yang menjadi Ketua MRP, Wakil Ketua I, dan Wakil Ketua II. Adanya perwakilan dari masingmasing kelompok kerja yang menjadi pimpinan lembaga MRP dapat memberikan motivasi bagi setiap anggota untuk dapat mengikutsertaan diri dalam pembahasan pemberian pertimbangan dan persetujuan terhadap rancangan Raperdasus.

Komitmen MRP dalam melaksanakan tugas dan wewenangnya untuk memberikan pertimbangan dan persetujuan terhadap rancangan Perdasus dapat dilihat pada tabel dibawah ini:

Tabel. 5

Persentase Kehadiran Anggota MRP Berdasarkan Kelompok KerjaDalam Memberikan Pertimbangan dan Persetujuan Raperdasus

\begin{tabular}{|c|c|c|c|}
\hline \multirow{2}{*}{ Kelompok Kerja } & \multicolumn{2}{|c|}{ Jumlah Anggota Pokja } & \multirow[b]{2}{*}{ Persentase } \\
\hline & Hadir & $\begin{array}{l}\text { Tidak } \\
\text { Hadir }\end{array}$ & \\
\hline Kelompok Kerja Adat & 9 & 3 & $75 \%$ \\
\hline Kelompok Kerja Perempuan & 7 & 5 & $58 \%$ \\
\hline Kelompok Kerja Agama & 10 & 2 & $83 \%$ \\
\hline
\end{tabular}

Sumber: Data primer diolah dari Risalah sidang MRP 2016.

Penyelenggaraan Pemerintah provinsi Papua dalam pembuatan peraturan daerah khusus (Perdasus) yang melibatkan Majelis Rakyat Papua (MRP) harus selalu mendapatkan dukungan oleh lembaga tersebut. Untuk itu, komitmen lembaga Majelis Rakyat Papua (MRP) dalam pembuatan peraturan daerah khusus (Perdasus) mendapatkan nilai 2.05 (Tinggi). Hal ini dikarenakan lembaga MRP selalu berjalan pada rel peraturan yang mengaturnya.

c. Peran MRP

Sejak diterapkannya Undang-undang No. 21 tahun 2001 tentang Otsus Papua memberikan perubahan terhadap penyelenggaraan sistem pemerintahan di provinsi Papua khususnya dalam hal lembaga pemerintahan. Perubahan dalam penyelenggaraan pemerintahan provinsi Papua dengan terbentuknya lembaga MRP sebagai lembaga representatif masyarakat kultur Papua. Lembaga MRP memiliki kewenangan dalam hal penyelenggaraan pemerintahan diantaranya terhadap pembentukan produk peraturan daerah. Kewenangan MRP dalam pembentukan produk peraturan daerah terlihat pada amanat Undang-undang No. 21 tahun 2001 menyatakan bahwa MRP berhak memberikan pertimbangan dan persetujuan terhadap Perdasus yang dibuat dan ditetapkan oleh DPRP bersama-sama Gubernur.

Pelaksanaan kewenangan MRP dalam memberikan pertimbangan dan persetujuan dipertegas kembali pada pasal 29 ayat 3 menyatakan tata cara pemberian pertimbangan dan persetujuan MRP diatur dalam Perdasi. Dengan adanya Undang-undang No. 21 tahun 2001 Otsus Papua, MRP diharapkan mampu memberikan kontribusi yang besar dalam penyelenggaraan pemerintahan di provinsi Papua khususnya dalam memperhatikan hakhak orang asli Papua.

MRP dalam memberikan pertimbangan dan persetujuan pembuatan Perdasus yang telah diatur dalam undang-undang Otsus Papua, diatur juga oleh PP No. 54 tahun 2004 bab 
IX tentang dalam pelaksanaan tugas dan wewenang MRP, yang kemudian diatur kembali oleh Perdasus No. 3 tahun 2008 tentang pelaksanaan hak dan kewajiban MRP. Selain itu lembaga MRP untuk melaksanakan tugas dan wewenangnya diatur juga dalam Perdasus No. 4 tahun 2008. Pada Pasal 8 Perdasus No. 4 tahun 2008 mengatakan DPRP menyampaikan rancangan Perdasus hasil pembahasan Gubernur dan DPRP kepada MRP untuk mendapatkan pertimbangan dan persetujuan.

Jika melihat kewenangan yang dimiliki oleh MRP, maka menjadikan MRP sebagai institusi yang memiliki kewenangan dalam penyelenggaraan pemerintahan provinsi Papua khususnya terhadap pembuatan Perdasus. Selain itu, MRP memiliki kembali peranan terhadap peraturan yang akan dibentuk oleh pemerintahan provinsi dan DPRP. Peranan yang dimiliki MRP selain memberikan pertimbangan dan persetujuan terhadap Perdasus tertuang pada Perdasus No. 4 tahun 2008 pasal 2 tentang tugas dan wewenang MRP yang menyatakan:

a. Memberikan pertimbangan dan persetujuan terhadap pasangan bakal calon Gubernur dan Wakil Gubernur yang diusulkan oleh DPRP;

b. Memberikan saran, pertimbangan dan persetujuan terhadap rencana kerjasama yang dibuat oleh pemerintah maupun pemerintahan provinsi dengan pihak ketiga yang berlaku di wilayah Papua, khususnya menyangkut perlindungan terhadap hak-hak orang asli Papua;

c. Memperhatikan dan menyalurkan aspirasi pengaduan masyarakat adat, umat beragama, kaum perempuan, dan masyarakat pada umumnya yang menyangkut dengan hak-hak OAP serta memfasilitasi tindak lanjut penyelesaiannya;

d. Memberikan pertimbangan kepada DPRP, Gubernur, DPRD Kabupaten/Kota serta Bupati/Walikota mengenai hal-hal yang terkait dengan perlindungan hak-hak OAP.

Keberadaan MRP selain memiliki tugas dan wewenang dalam memberikan pertimbangan dan persetujuan, MRP juga memiliki hak dan kewajiban yang harus dilaksanakan.Hal ini tertuang dalam Perdasus No. 3 tahun 2008 tentang pelaksanaan hak dan kewajiban MRP. Selanjutnya pada pasal 2 tentang hak MRP menyatakan bahwa:

a. Meminta keterangan kepada pemerintahan provinsi, Kabupaten/Kota mengenai hal-hal yang terkait dengan perlindungan hak-hak OAP;

b. Meminta peninjauan kembali Perdasi atau peraturan Gubernur yang dinilai bertentangan dengan perlindungan hak-hak OAP;

Kewenangan MRP sebagai salah satu lembaga pemerintahan daerah yang setara dengan pemerintahan provinsi dan DPRP memiliki tugas diantaranya memberikan pertimbangan dan persetujuan terhadap Perdasus.Disinilah peran MRP sebagaimana yang telah diamanatkan undang-undang Otsus tersebut.Sebagai lembaga penyelenggara pemerintahan daerah dan sebagai mitra kerja yang memiliki tugas dan wewenang terhadap pembentukan Perdasus, maka kami dilingkungan MRP harus tetap menjalankan tugas dan kewenangan tersebut.

Sebagai mitra kerja lembaga pemerintahan daerah provinsi dalam pelaksanaan Otsus Papua, MRP merupakan bagian yang tak terpisahkan atau satu kesatuan dari DPRP dan Gubernur yang memiliki derajat yang sama dalam membuat keputusan (decision making). Untuk itu, lembaga MRP dalam pemberian pertimbangan dan persetujuan terhadap Raperdasus sangat sangat diperlukan.

Namun, Peran MRP terhadap pembentukan Perdasus hanya sebatas memberikan pertimbangan dan persetujuan. Pemberian pertimbangan tersebut dilakukan melalui kelompok-kelompok kerja yang ada dilingkungan MRP, selanjutnya disidangkan bersama- 
sama dengan seluruh anggota MRP untuk mendapatkan kesepatakan dan memberikan rekomendasi terhadap butir-butir dari muatan yang terkandung dalam Perdasus itu.

Selain memiliki kewenangan dalam proses pembentukan peraturan yang bersifat khusus, MRP juga memiliki hak kewenangan untuk melakukan peninjauan kembali terhadap Perdasi, peraturan kepala daerah atau kebijakan-kebijakan daerah yang bertentangan dengan hak-hak orang asli Papua (OAP). Jika kebijakan-kebijakan itu betentangan, maka MRP akan meminta peninjauan kembali terkait dengan pasal-pasal dan juga MRP tidak sekedar meminta peninjauan kembali tetapi memberikan solusi dengan membuat rancangan-rancangan koreksi. Dalam konteks ini, MRP telah memiliki peran.

MRP dalam melaksanakan tugas dan wewenangnya untuk memberikan pertimbangan dan persetujuan terhadap rancangan Perdasus dapat dilihat pada tabel dibawah ini:

Tabel. 6

Rapat Dengar Pendapat MRPPemberian Pertimbangan dan Persejutuan Raperdasus

\begin{tabular}{|c|c|c|c|}
\hline \multirow[b]{2}{*}{ Perdasus } & \multicolumn{2}{|c|}{ Jumlah Anggota MRP } & \multirow[b]{2}{*}{ Prosentase } \\
\hline & Hadir & $\begin{array}{l}\text { Tidak } \\
\text { Hadir }\end{array}$ & \\
\hline $\begin{array}{l}\text { Pengelolaan Keuangan Khusus di Provinsi } \\
\text { Papua }\end{array}$ & 33 & 9 & $78 \%$ \\
\hline $\begin{array}{l}\text { Perubahan Perdasus No. } 6 \text { Tahun } 2014 \text { tentang } \\
\text { Keanggotaan DPRP yang ditetapkan melalui } \\
\text { Mekanisme Pengangkatan periode 2014-2019 }\end{array}$ & 37 & 5 & $88 \%$ \\
\hline $\begin{array}{llll}\text { Pengelolaan } & \text { Pertambangan } & \text { Mineral } & \text { dan } \\
\text { Batubara } & & & \\
\end{array}$ & 23 & 19 & $54 \%$ \\
\hline $\begin{array}{l}\text { Perubahan Perdasus No. 25 Tahun } 2013 \\
\text { tentang Penerimaan Pengelolaan Keuangan } \\
\text { DOK }\end{array}$ & 39 & 3 & $92 \%$ \\
\hline
\end{tabular}

Sumber: Data primer diolah dari Risalah Rapat MRP.

Tabel. 7

Rekomendasi Rapat Dengar

Pendapat MRP

\section{Kesepakatan Rekomendasi}

Kebijakan khusus belanja daerah perlu diatur dalam peraturan pengelolaan keuangan khusus provinsi Papua. Namun, dalam pengelolaan keuangan tersebut diharapkan transparansi, bertanggung jawab, dan dengan memperhatikan asas keadilan serta bermanfaat untuk masyarakat dan penguatan untuk orang asli Papua.

Keanggotaan DPRP melalui daerah pengangkatan perlu dilakukan untuk mengakomodir peran serta dari masyarakat asli Papua dalam memperjuangkan aspirasi pada proses penyelenggaraan pembangunan daerah. 
Kekayaan SDA di Provinsi sangat besar, untuk itu perlu diatur pengelolaan secara optimal demi kepentingan pada kesejahteraan rakyatnya pada saat sekarang hingga akan datang secara adil dan tentunya harus mempertimbangan kelangsungan kesejahteraan masyarakat secara umum dan lebih khususnya lagi bagi kepentingan orang asli Papua (OAP)

Perlu adanya pembangunan perumahan rakyat layak huni bagi OAP, mengingat rakyat Papua yang berada di daerah terpencil dengan keterbatasan ekonomi masih jauh dari kesejahteraan. Apa lagi DOK ini diperuntukkan dalam bidang pembangun an pendidikan, kesehatan, ekonomi, dan infrastruktur.

Sumber: Data primer diolah dari Risalah Rapat MRP.

Pelaksanaan tugas dan wewenang lembaga MRP dalam memberikan pertimbangan dan persetujuan terhadap Raperdasus dapat dikatakan terlaksana dengan baik, hal ini ditandai dengan tingkat keikutsertaan anggota MRP terhadap pemberian pertimbangan dan persetujuan Perdasus. Disisi yang lain, lembaga MRP menyadari akan tugas dan kewenangan yang harus dilaksanakan sebagai bentuk pertanggungjawaban terhadap orang asli Papua dan menyadari bahwa kehadiran MRP untuk memperhatikan kepentingan hak-hak orang asli Papua. Hal ini juga disadari oleh setiap anggota lembaga MRP bahwa kehadiran mereka yang terhimpun dalam lembaga tersebut untuk memberikan pertimbangan dan persetujuan terhadap pembentukan Perdasus sangat diperlukan, karena apabila MRP tidak memberikan persetujuan maka Perdasus tersebut dianggap tidak sah. Sehingganya peraturan untuk mengakomodir kepentingan masyarakat asli orang Papua tidak terlaksana.

Penyelenggaraan Pemerintah provinsi Papua dalam pembuatan peraturan daerah khusus (Perdasus) yang melibatkan Majelis Rakyat Papua (MRP) harus selalu mendapatkan dukungan oleh lembaga tersebut. Untuk itu, peran lembaga Majelis Rakyat Papua (MRP) dalam pembuatan peraturan daerah khusus (Perdasus) mendapatkan nilai 2.0 (Tinggi). Hal ini dikarenakan lembaga MRP sesuai dengan kewenangan yang dimiliki memberikan pertimbangan dan persetujuan terhadap rancangan peraturan daerah khusus.

\section{d. Mekanisme MRP}

Dalam penyelenggaraan pemerintahan provinsi Papua, lembaga MRP hadir dengan diberikannya kewenangan terhadap pembentukan produk peraturan daerah. Kewenangan MRP dalam pembentukan produk peraturan daerah terlihat pada amanat Undang-undang No. 21 tahun 2001 menyatakan bahwa MRP berhak memberikan pertimbangan dan persetujuan terhadap Perdasus yang dibuat dan ditetapkan oleh DPRP bersama-sama Gubernur.

Lembaga MRP yang hadir sebagai lembaga representatif masyarakat kultur Papua tidak memiliki kewenangan dalam penyusunan/pembuatan peraturan daerah terlebih pada peraturan daerah khusus (Perdasus) sebagaimana yang telah diamanatkan oleh undangundangan. Artinya, lembaga MRP tidak terlibat langsung secara mandiri atau tidak memiliki hak legislasi dalam penyusunan/pembuatan Perdasus.

Kehadiran lembaga MRP dalam tatanan pemerintahan provinsi Papua hanya sebatas memberikan pertimbangan dan persetujuan. Kewenangan lembaga MRP ini disebutkan dalam UU No. 21 tahun 2001 pasal 20 yang menyatakan bahwa:

(1) MRP mempunyai tugas dan wewenang:

a. memberikan pertimbangan dan persetujuan terhadap bakal calon Gubernur dan Wakil

Gubernuryang diusulkan oleh DPRP; 
b. memberikan pertimbangan dan persetujuan terhadap calon anggota Majelis PermusyawaratanRakyat Republik Indonesia utusan daerah Provinsi Papua yang diusulkan oleh DPRP;

c. memberikan pertimbangan dan persetujuan terhadap Rancangan Perdasus yang diajukan olehDPRP bersama-sama dengan Gubernur;

d. memberikan saran, pertimbangan dan persetujuan terhadap rencana perjanjian kerjasama yangdibuat oleh Pemerintah maupun Pemerintah Provinsi dengan pihak ketiga yang berlaku di Provinsi Papua khusus yang menyangkut perlindungan hak-hak orang asli Papua;

e. memperhatikan dan menyalurkan aspirasi, pengaduan masyarakat adat, umat beragama, kaum perempuan dan masyarakat pada umumnya yang menyangkut hakhak orang asli Papua,memfasilitasi tindak lanjut penyelesaiannya; dan

f. memberikan pertimbangan kepada DPRP, Gubernur, DPRD Kabupaten/Kota serta Bupati/Wakil Bupati mengenai hal-hal yang terkait dengan perlindungan hak-hak orang asli Papua.

(2) Pelaksanaan tugas dan wewenang sebagaimana dimaksud pada ayat (1) diatur denganPerdasus.

Tugas dan wewenang lembaga MRP sebagaimana yang telah disebutkan dalam undang-undang Otsus Papua, diatur juga oleh PP No. 54 tahun 2004 bab IX tentang tugas dan wewenang MRP disebutkan dalam pasal 36 yang menyatakan bahwa:

MRP mempunyai tugas dan wewenang:

a. memberikan pertimbangan dan persetujuan terhadap pasangan bakal calon Gubernur dan Wakil Gubernur yang diusulkan oleh DPRP;

b. memberikan pertimbangan dan persetujuan terhadap rancangan Perdasus yangdiajukan oleh DPRP bersama-sama dengan Gubernur;

c. memberikan saran, pertimbangan dan persetujuan terhadap rencana perjanjiankerjasama yang dibuat oleh pemerintah maupun pemerintah provinsi dengan pihakketiga yang berlaku di wilayah Papua, khusus ya ng menyangkut perlindungan hak-hakorang asli Papua;

d. memperhatikan dan menyalurkan aspirasi pengaduan masyarakat adat, umatberagama, kaum perempuan dan masyarakat pada umumnya yang menyangkut hak-hakorang asli Papua serta memfasilitasi tindak lanjut penyelesaiannya;

e. memberikan pertimbangan kepada DPRP, Gubernur, DPRD kabupaten/kota sertaBupati/Walikota mengenai hal-hal yang terkait dengan perlindungan hak-hak orang asli Papua.

Pelaksanaan tugas dan wewenang lembaga MRP sebagai representatif masyarakat kultur Papua dalam penyelenggaraan pemerintahan provinsi Papua terutama terhadap penyusunan/pembuatan rancangan peraturan daerah diatur oleh Perdasus No. 3 tahun 2008 tentang pelaksanaan hak dan kewajiban MRP. Selain itu lembaga MRP untuk melaksanakan tugas dan wewenangnya diatur juga dalam Perdasus No. 4 tahun 2008.

Terkait dengan penyusunan/pembuatan peraturan daerah, lembaga MRP hanya terlibat dalam memberikan pertimbangan dan persetujuan terhadap rancangan peraturan daerah. Untuk itu, mekanisme pelaksanaan tugas oleh lembaga MRP sebagaimana yang disebutkan dalam Perdasus No. 4 tahun 2008 pasal 8 yang menyatakan bahwa:

a. DPRP menyampaikan Rancangan Perdasus hasil Pembahasan Gubernur dan DPRP kepada MRP untuk mendapatkan pertimbangan dan persetujuan;

b. Rancangan Perdasus hasil Pembahasan Gubernur dan DPRP sebagaimana dimaksud pada ayat (1) terdiri atas :

1. Surat pengantar yang ditandatangani oleh Pimpinan DPRP; dan 
2. Rancangan Perdasus yang telah memperolehpersetujuan dari Gubernur dan Pimpinan DPRP.

c. Sekretaris MRP melakukan pemeriksaan kelengkapan administratif Rancangan Perdasus sebagaimana dimaksud pada ayat (2) untuk waktu paling lama 2 (dua) hari kerja setelah diterima dari DPRP;

d. Sekretaris MRP menyampaikan Rancangan Perdasus sebagaimana dimaksud pada ayat (2) yang dinyatakan lengkap kepada Pimpinan MRP untuk dilanjutkan kepada Pokja atau lintas Pokja guna dilakukan pembahasan; dan

e. Apabila hasil pemeriksaan persyaratan administratif Rancangan Perdasus sebagaimana dimaksud pada ayat (2) dinyatakan tidak lengkap, Sekretaris MRP menyerahkan kembali kepada DPRP untuk dilengkapi.

Mekanisme pemberian pertimbangan dan persetujuan yang dilakukan oleh lembaga MRP, selanjutnya pada pasal 9 Perdasus No. 4 tahun 2008 menyatakan bahwa:

a. Pimpinan MRP menetapkan Pokja atau lintas Pokja untuk membahas Rancangan Perdasus untuk waktu paling lama 20 (dua puluh) hari kerja;

b. Pokja atau lintas pokja sebagaimana dimaksud pada ayat (1) dalam melakukan pembahasan Rancangan Perdasus, wajib:

1. Memperolehpendampingan narasumber ahli yang berkaitandengan materi muatan RancanganPerdasus;

2. mendokumentasi proses secara audiovisual dan tulisan; dan

3. melakukan kajian terhadap materi muatan Rancangan Perdasus mengenai hal-hal yang terkait dengan perlindungan hak-hak orang asli Papua.

c. Pokja atau lintas Pokja dalam melakukan pembahasan Rancangan Perdasus dapat mengundang dan menghadirkan:

1. parawakil unsur masyarakat yang menjadisasaranpelaksananRancangan Perdasus untuk mendapatpenjelasan atau pandanganyang berkaitan dengan materi muatan Rancangan Perdasus; dan

2. utusan Pemerintah Provinsi dan/atau utusanDPRP untukmendapatkan penjelasanklarifikasiberkaitan denganmaterimuatanRancangan Perdasus.

Selanjutnya pada pasal 10 Perdasus No. 4 tahun 2008, mekanisme pemberian pertimbangan dan pesetujuan Perdasus dilingkungan lembaga MRP menyatakan bahwa:

1. Pokja atau lintas Pokja menyampaikan hasil pembahasan Rancangan Perdasus kepada Pimpinan MRP dalam bentuk persetujuan atau penolakan;

2. Hasil pembahasan Pokja atau lintas Pokja sebagaimana dimaksud pada ayat (1) yang memberikan persetujuan, dapat berupa:

1. Persetujuan terhadap seluruh materi muatan disertai alasannya; atau

2. pestujuan terhadap sebagian materi muatan disertai alasan dan rumusan perbaikan.

3. Hasil pembahasan Pokja atau lintas Pokja sebagaimana dimaksud pada ayat (1) yang berupa penolakan, harus disertai alasan penolakan terhadap Rancangan Perdasus dan rumusan perbaikan.

Mekanisme lembaga MRP dalam memberikan pertimbangan dan persetujuan terhadap rancangan Perdasus, sellanjutnya tertuang di dalam pasal 11 Perdasus No. 4 tahun 2008 yang menyatakan bahwa:

a. Pimpinan MRP melakukan penetapan Rancangan Perdasus hasilpembahasanPokja atau lintas Pokja dalam rapatpleno; 
b. Sekretaris MRPataspersetujuan Pimpinan MRP,menyampaikanhasil penetapan Rancangan Perdasus yang mendapatkanpersetujuansebagaimanadimaksudpada ayat(1)kepada DPRP untukditetapkan menjadiPerdasus;

c. SekretarisMRPatas persetujuan pimpinan MRPmenyampaikanhasil penetapan Rancangan Perdasus yangberupapenolakan $\begin{array}{llll}\text { kepadaDPRPuntukdilakukanpembahasanbersama untuk } & \text { waktupalinglama } & 8\end{array}$ (delapan)harikerja; dan

d. Pembahasanbersamasebagaimana dimaksud pada ayat (3)dilakukan dalam Rapat Kerja MRP yang harus diikuti olehPemerintah Provinsi dan DPRP.

Lembaga MRP tidak memiliki hak dalam penyusunan/pembentukan rancangan peraturan daerah secara khusus yang lebih mengatur kepentingan masyarakat asli Papua. Kehadiran lembaga MRP dalam pembentukan produk peraturan daerah hanya dapat memberikan pertimbangan dan persetujuan.

Majelis Rakyat Papua (MRP) dalam kewenangannya memeperhatikan hak orang asli Papua terutama dalam hal regulasi.Produk regulasi seperti Perdasus disusun oleh pihak eksektutif disampaikan kepada DPRP, dan sebelum disahkan segerah diserahkan ke MRP untuk dipelajari/dikaji.Jadi, kewenangan MRP dalam hal pembuatan produk regulasi daerah hanya memberikan pertimbangan dan persetujuan terhadap Perdasus.MRP dalam memberikan pertimbangan dan persetujuan dilakukan pembahasan dan pengkajian di internal kelompok kerja, setelah itu lalu di plenokan bersama-sama unsur pimpinan dilingkuangan MRP.Dalam rapat pleno akan disampaikan alasan-alasan apakah Raperdasus tersebut disetujui atau dilakukan perubahan dalam pasal-pasal dan dituliskan rekomendasi atas perubahan-perubahan tersebut.

Mekanisme dalam pemberian pertimbangan dan persetujuan dalam pembuatan Perdasus dilingkungan MRP dilakukan dengan cara setiap rancangan Perdasus yang telah disepakati oleh pihak pemerintahan provinsi dan DPRP disampaikan ke MRP melalui biro umum Sekretaris Majelis dan kemudian disampaikan ke pimpinan, setelah itu pimpinan menyampaikan ke kelompok kerja untuk dilakukan pembahasan di internal kelompok kerja berdasarkan tupoksinya masing-masing. Ketika pembahasan di internal kelompok kerja telah selesai lalu disampaikan kepada pimpinan untuk dibahas kembali melalui rapat pleno MRP.

Selanjutnya, mekanisme pemberian pertimbangan dan persetujuan terhadap rancangan Perdasus dimana pelaksanaan tugas lembaga MRP dalam memberikan pertimbangan dan persetujuan terhadap rancangan Perdasus sudah diatur yang terdapat pada Perdasus No. 4 tahun 2008 dan PP No. 54 tahun 2004. Jadi, rancangan Perdasus yang di telah disampaikan ke lembaga MRP untuk dilakukan pembahasan dengan unsur-unsur pimpinan beserta anggota MRP.

Mekanisme pemberian pertimbangan dan persetujuan terhadap rancangan Perdasus yang dilakukan oleh lembaga MRP dapat dilihat secara jelas pada gambar dibawah ini: 
Gambar. 1

Mekanisme Pemberian Pertimbangan dan Persetujuan Raperdasus

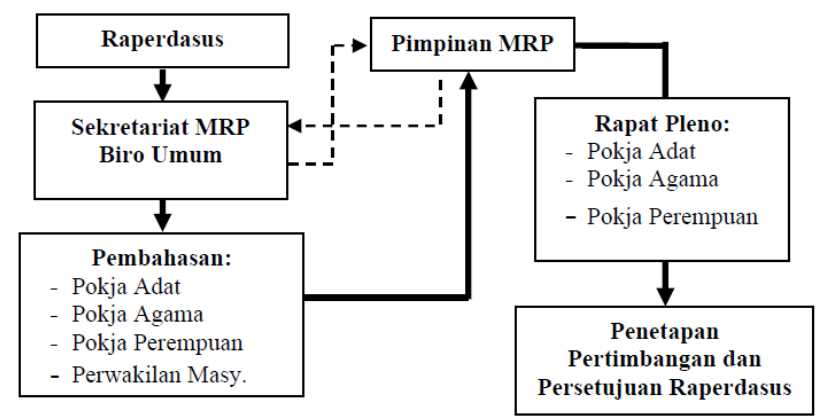

Sumber:Elaborasi Penulis berdasarkan Perdasus No. 4 Tahun 2008 dan PP No. 54 Tahun 2004.

Hasil wawancara diatas menunjukkan bahwa pelaksanaanmekanisme lembaga MRP dalam pemberian pertimbangan dan persetujuan terhadap rancangan Perdasus telah dilakukan berdasarkan peraturan. Hal tersebut menandakan bahwa lembaga MRP khsusunya pihak-pihak yang berada dilingkungannya berpegang teguh pada regulasi yang diterapkan dalam menjalankan roda lembaga MRP sebagai salah satu penyelenggara pemerintahan di provinsi Papua.Pelaksanaan mekanisme pemberian pertimbangan dan persetujuan terhadap rencangan Perdasus yang berpegang teguh pada regulasi dikarenakan kesadaran dari masing-masing anggota lembaga MRP bahwa dalam menjalankan organisasi harus berdasarkan dengan ketentuan yang telah ditetapkan.

Pelaksanaan mekanisme Majelis Rakyat Papua (MRP) dalam memberikan pertimbangan dan persetujuan dalam pembuatan peraturan daerah khusus (Perdasus) mendapatkan nilai 2,1 (Tinggi). Hal ini dikarenakan lembaga MRP dalam memberikan pertimbangan dan persetujuan selalu melakukan mekanisme yang telah ditentukan peraturan perundang-undangan.

\section{KESIMPULAN}

\section{a. Keterlibatan MRP}

Keterlibatan MRP dalam pembuatan Perdasus sangat terbatas dengan kewenangan yang dimilikinya berdasarkan ketentuan peraturan.Kewenangan lembaga MRP hanya melakukan pemberian pertimbangan dan persetujuan pada peraturan daerah khusus (Perdasus). Walaupun kewenangan yang dimiliki lembag MRP sangat terbatas, namun lembaga MRP dalam proses memberikan pertimbangan dan persetujuan terhadap Perdasus sudah terlaksana dengan maksimal, hal ini ditandai dengan jumlah presentasi kehadiran anggota MRP melebihi $50 \%$ kehadiran dalam sidang pemberian pertimbangan dan persetujuan.

Keterlibatan lembaga pemerintahan provinsi Papua dalam hal ini Majelis Rakyat Papua (MRP) dari hasil jawaban responden sebanyak 20 orang makalembaga Majelis Rakyat Papua (MRP) tidak terlalu terlibat dengan mendapatkan nilai 1,35 (Sedang). Hal ini dikarenakan lembaga MRP hanya berada pada tingkat memberikan persetujuan saja terhadap rancangan yang telah disepakati oleh eksekutif dan legistatif.

\section{b. Komitment MRP}

Komitmen lembaga MRP dalam melaksanakan kewenangan yang dimilikinya untuk memberikan pertimbangan dan persetujuan terhadap Raperdasus dapat dikatakan terlaksana dengan baik, hal ini ditandai dengan tingkat presentasi kehadiran anggota MRP dari masingmasing kelompok kerja yang menunjukan melebihi 50\%.Tingkat kehadiran anggota MRP yang 
begitu antusias dari masing-masing kelompok kerja ini dikarenakan setiap kelompok kerja ada yang menjadi Ketua MRP, Wakil Ketua I, dan Wakil Ketua II. Adanya perwakilan dari masingmasing kelompok kerja yang menjadi pimpinan lembaga MRP dapat memberikan motivasi bagi setiap anggota untuk dapat mengikutsertaan diri dalam pembahasan pemberian pertimbangan dan persetujuan terhadap rancangan Raperdasus.

Penyelenggaraan Pemerintah provinsi Papua dalam pembuatan peraturan daerah khusus (Perdasus) yang melibatkan Majelis Rakyat Papua (MRP) harus selalu mendapatkan dukungan oleh lembaga tersebut. Untuk itu, komitmen lembaga Majelis Rakyat Papua (MRP) dalam pembuatan peraturan daerah khusus (Perdasus) mendapatkan nilai 2.05 (Tinggi). Hal ini dikarenakan lembaga MRP selalu berjalan pada rel peraturan yang mengaturnya.

\section{c. Peran MRP}

Pelaksanaan tugas dan wewenang lembaga MRP dalam memberikan pertimbangan dan persetujuan terhadap Raperdasus dapat dikatakan terlaksana dengan baik, hal ini ditandai dengan tingkat keikutsertaan anggota MRP terhadap pemberian pertimbangan dan persetujuan Perdasus. Disisi yang lain, lembaga MRP menyadari akan tugas dan kewenangan yang harus dilaksanakan sebagai bentuk pertanggungjawaban terhadap orang asli Papua dan menyadari bahwa kehadiran MRP untuk memperhatikan kepentingan hak-hak orang asli Papua. Hal ini juga disadari oleh setiap anggota lembaga MRP bahwa kehadiran mereka yang terhimpun dalam lembaga tersebut untuk memberikan pertimbangan dan persetujuan terhadap pembentukan Perdasus sangat diperlukan, karena apabila MRP tidak memberikan persetujuan maka Perdasus tersebut dianggap tidak sah. Sehingganya peraturan untuk mengakomodir kepentingan masyarakat asli orang Papua tidak terlaksana.

Penyelenggaraan Pemerintah provinsi Papua dalam pembuatan peraturan daerah khusus (Perdasus) yang melibatkan Majelis Rakyat Papua (MRP) harus selalu mendapatkan dukungan oleh lembaga tersebut. Untuk itu, peran lembaga Majelis Rakyat Papua (MRP) dalam pembuatan peraturan daerah khusus (Perdasus) mendapatkan nilai 2.0 (Tinggi). Hal ini dikarenakan lembaga MRP sesuai dengan kewenangan yang dimiliki memberikan pertimbangan dan persetujuan terhadap rancangan peraturan daerah khusus.

\section{d. Mekanisme MRP}

Pelaksanaanmekanisme lembaga MRP dalam pemberian pertimbangan dan persetujuan terhadap rancangan Perdasus telah dilakukan berdasarkan peraturan. Hal tersebut menandakan bahwa lembaga MRP khsusunya pihak-pihak yang berada dilingkungannya berpegang teguh pada regulasi yang diterapkan dalam menjalankan roda lembaga MRP sebagai salah satu penyelenggara pemerintahan di provinsi Papua.Pelaksanaan mekanisme pemberian pertimbangan dan persetujuan terhadap rencangan Perdasus yang berpegang teguh pada regulasi dikarenakan kesadaran dari masing-masing anggota lembaga MRP bahwa dalam menjalankan organisasi harus berdasarkan dengan ketentuan yang telah ditetapkan.

Pelaksanaan mekanisme Majelis Rakyat Papua (MRP) dalam memberikan pertimbangan dan persetujuan dalam pembuatan peraturan daerah khusus (Perdasus) mendapatkan nilai 2,1 (Tinggi). Hal ini dikarenakan lembaga MRP dalam memberikan pertimbangan dan persetujuan selalu melakukan mekanisme yang telah ditentukan peraturan perundang-undangan. 


\section{REFERENSI}

Kaho, J. Riwu, (2012). Analisis Hubungan Pemerintah Pusat dan Daeah Di Indonesia. Cet. 3-Yogyakarta: Center for Politics and Government (PolGov) Fisipol UGM.

Kelle, Udo. (2001). Sociological Explanation Between Micro and Macro and the Integration of Qualitative and Quantitative Methods. Jurnal: Forum Qualitative Social Research. Vol. 2 No. 1, Februari 2001.

Mallarangeng, A. Andi (2006). Blue Print: Otonomi Daerah Indonesia. Ed. 1, Jakarta: Yayasan Harkat Bangsa.

Makmur. (2011). Efektivitas Kebijakan Kelembagaan Pengawasan. Bandung: Refika Aditam.

Provan, Keith. G, and Kenis, Patrick (2007). Modes of Network Governance: Structure, Management, and Effectiveness. Journal of Public Administration Research and Theory, Oxford University Press.

Sugiyono, (2014). Metode Penelitian Kuantitatif, Kualitatif, dan R\&D. Cet: 20 - Bandung: Alfabeta.

Wisnu UR, D dan Nurhasanah, S. 2005. Teori Organisasi Struktur dan Desain. UMM Press, Malang.

Undang-Undang No. 21 Tahun 2001 tentang Otonomi Khusus Papua.

Undang-Undang No. 12 Tahun 2011 tentang Pembentukan Peraturan Perundang-undangan.

Peremdagri No. 80 Tahun 2015 tentang Pembentukan Peraturan Perundang-undangan.

Peraturan Pemerintah No. 54 Tahun 2004 tentang Majelis Rakyat Papua.

Peraturan DPRP Nomor 02 Tahun 2010 tentang Perubahan Atas Tata Tertib Dewan Perwakilan Rakyat Papua.

Peraturan DPRP Nomor 01 Tahun 2009 tentang Tata Tertib Dewan Perwakilan Rakyat Papua.

Peraturan Daerah Provinsi Papua No. 9 Tahun 2010 tentang Pembentukan Peraturan Daerah Provinsi dan Peraturan Daerah Khusus.

Peraturan Daerah Khusus No. 4 Tahun 2008 tentang Pelaksanaan Tugas dan Wewenang MRP.

Peraturan Daerah Khusus No. 3 Tahun 2008 tentang Pelaksanaan Hak dan Kewajiban MRP.

Peraturan DPRP No. 1 Tahun 2014 tentang Tata Tertib Dewan Perwakilan Rakyat Papua. 